J. Clin. Chem. Clin. Biochem.

Vol. 26, 1988, pp. 697-703

(C) 1988 Walter de Gruyter \& Co.

Berlin - New York

\title{
Automated Determination of Serum (Plasma) and Urine Iron: A Comparative Investigation of Chromogens Improved Tripyridyltriazine Micromethod
}

By $E$. Solem

Klinisch-chemisches Labor, Zentrum der Kinderheilkunde der Universitätskliniken Frankfurt am Main

U. B. Seiffert

Zentrallabor, Zentrum der Inneren Medizin der Universitätskliniken Frankfurt am Main

U. Jalner, M. Kaul

Klinisch-chemisches Labor, Zentrum der Kinderheilkunde der Universitätskliniken Frankfurt am Main

L. J. Behnken

Bioscientia Institut für Laboruntersuchungen Ingelheim $\mathrm{GmbH}$, Mainz

K. Fröhlich

Medizinisch-technische Untersuchungsstelle der Bundesversicherungsanstalt für Angestellte, Frankfurt am Main and

M. Zirker

Zentrallabor, Zentrum der Inneren Medizin der Universitätskliniken Frankfurt am Main

(Received March 28/August 1, 1988)

Summary: Four different, well known colour reagents for iron determination were tested in a citrate buffer at $\mathrm{pH} 2.0$ under the same automated standard conditions and compared with a manual reference method on human serum and plasma samples. Specific results were obtained only with the chromogen tripyridyl-striazine. A micromethod was developed, which is generally well suited for automated, direct serum iron determinations, with respect to good flow properties, simple reagent composition, high reagent stability, rapid colour development, stable colour complex and high specificity. This method was run on either a Gilford System 203 S, Gilford Impact 400 or a Greiner G-400 analyser and adapted to the Technicon SMAC II, Technicon RA 1000, Eppendorf Epos and Abbott Spectrum automated systems. The tripyridyl-s-triazine method permits the determination of ferrioxamine iron in urine after a simple sample pretreatment.

\section{Introduction}

The first automated method for serum iron measurement was developed on a continuous flow system with the chromogen tripyridyl-s-triazine (1). Subsequently, several other automated methods for serum iron determination have been introduced in the routine laboratory $(2-9)$. These methods were mainly based on the colour reagents bathophenanthroline sulphonate 
and ferrozine. The latter chromogen has a somewhat higher molar absorptivity than tripyridyl-s-triazine and bathophenanthroline sulphonate. Later, ferene$S$, a chromogen with improved molar absorptivity and the same features as ferrozine, with respect to slow colour development and interference by copper (10), was introduced for serum iron determination (11). The relatively slow colour development in the ferrozine reaction was found to be a limiting factor in some analysers (6). Interference by copper can be eliminated with thiosemicarbazide, which forms an uncoloured complex with copper (10). Reaction of thiosemicarbazide with ascorbic acid impairs reagent stability. If the test is not performed at sufficiently acidic $\mathrm{pH}$, interference by released haemoglobin iron may arise (10). Such difficulties may easily impair the specificity of the measurement, in particular in the clinically important, abnormally low range. We searched for an improved, automated method for serum iron determination, which overcomes these problems.

\section{Materials and Methods}

Chemicals

Bathophenanthroline sulphonate (4,7-diphenyl-1,10-phenanthroline disulphonic acid sodium salt), TPTZ (2,4,6-tripyridyls-triazine), ferrozine (3-(2-pyridyl)-5,6-bis(4-phenylsulphonic acid)-1,2,4-triazine sodium salt) and ferene-S (3-(2-pyridyl)-5,6bis(2-(5-furyl-sulphonic acid))-1,3,4-triazine disodium salt) were from Sigma Chem. Corp., Duishofen, FRG. Other analytical grade reagents were obtained from E. Merck Darmstadt, FRG. The iron standard was either from Boehringer Mannheim, FRG $(17.9 \mu \mathrm{mol} / \mathrm{l})$ or prepared from a stock solution, containing $895.5 \mu \mathrm{mol} / 1$ iron. The stock solution was made by dissolving reduced iron in approx $6 \mathrm{~mol} / \mathrm{l} \mathrm{HCl}$, followed by dilution to 11 with distilled water.

\section{Serum and plasma samples}

Control sera were obtained from E. Merck, Darmstadt, FRG (Seronorm), from Beckman, Munich, FRG (Decision Level $1-3$ ) and from Behringwerke, Marburg, FRG (KontrollogenLP).

Serum or plasma samples from patients with normal and pathological iron values were used. Sampling was performed between 8 and 9 a. m. under fasting conditions. Tubes containing ammonium heparinate were used for obtaining plasma.

\section{Instrumentation}

In the present investigation, serum (plasma) iron and urine desferal iron determinations were performed either on a Gilford System 203 S, a Gilford Impact 400 Analyser (Gilford Instruments, Oberlin, OH, USA) or a Greiner G-400 analyser (Greiner Instruments $\mathrm{GmbH}$, Birkenfeld, FRG). Only the tripyridyl-striazine method was adaptable to the Greiner G-400 (at $37^{\circ} \mathrm{C}$ ). Atomic absorption spectrophotometric determinations of iron in urine were performed on a Perkin-Elmer 2380 system (PerkinElmer Corp., Norwalk, Ct., USA).

\section{Reagents}

The reagent for sample blanks (reagent 1) consisted of 0.24 $\mathrm{mol} / \mathrm{l}$ aqueous citric acid monohydrate $(50 \mathrm{~g} / 1+1$ drop of chloroform) and $5.6 \mathrm{mmol} / \mathrm{l}$ ascorbic acid. The colour reagent (reagent 2) consisted of $1.6 \mathrm{mmol} / 1$ of one of the reagents, tripyridyl-s-triazine, bathophenanthroline sulphonate, ferrozine or ferene-S dissolved in reagent 1 . Totali bilirubin was measured on a Greiner G-400 with the dichloroaniline method (kit from Greiner No. 4057).

\section{Method for serum (plasma) examinations}

The methods were run with sample and reagent blanks at $25^{\circ} \mathrm{C}$ on the Gilford Systems with four different standards $(2.2,4.5$, 9.0 and $17.9 \mu \mathrm{mol} / \mathrm{l}$ ) and at $37^{\circ} \mathrm{C}$ on the Greiner G-400 with or without standards. Details for the programming of these systems are listed in table 1 . The measurements were performed at a wavelength of 593, 533, 562 and $593 \mathrm{~nm}$ with tripyridyl-striazine, bathophenanthroline sulphonate, ferrozine and ferene$\mathrm{S}$, respectively. The tripyridyl=s-triazine/citrate method was found to be linear up to at least $260 \mu \mathrm{mol} / \mathrm{l}$. For the examination of urine samples, higher standards were used (see below). The systems were accepted for use when they showed linearity for the different standards (automatically checked) and/or a withinrun precision of $2 \%$ or less in a control serum (Decision Level 2). Otherwise, a cleaning of the system with $0.1 \mathrm{~mol} / 1 \mathrm{HCl}$ and/ or a photometer check (lamp drift) was performed. After an initial cleaning with $\mathrm{HCl}$, problems of contamination normally do not occur in selective analysers such as the Greiner G-400 and comparable systems.

Tab. 1. Data on the programming of the Gilford systems and the Greiner G-400.

\begin{tabular}{lr}
\hline Gilford \\
\hline WAWELENGTH & 593 \\
TRANSPORT TEMP. & 25 \\
CUVETTE TEMP. & 25 \\
SAMPLE VOLUME & 40 \\
VOLUME DISP. A & 100 \\
VOLUME DISP. B & 300 \\
VOLUME DISP. C & 300 \\
READ TIME & 3 \\
EQUIL. TIME & 5 \\
TIME A TO B & 2 \\
TIME A TO C & 2 \\
LAG TIME & 300
\end{tabular}

Greiner G-400

$\begin{array}{lcr}\text { MODE } & 50 & \\ \text { N/U } & 39 & 0 \\ \text { PT1 } & 030 & 030 \\ \text { PT2 } & 030 & 030 \\ \text { FILTER } & 7000 & 0 \\ \text { R1 } & 01 & 39 \\ \text { R2 } & 10 & 38 \\ \text { A } & 5494 & \\ \text { B } & -13 & \\ \text { VOLUME R1 } & 400 & \\ \text { VOLUME R2 } & 400 & \\ \text { SAMPLE VOLUME } & 30 & \end{array}$


趽ediea-

Treffipunkt 1988

Aus Tradition in Halle 4

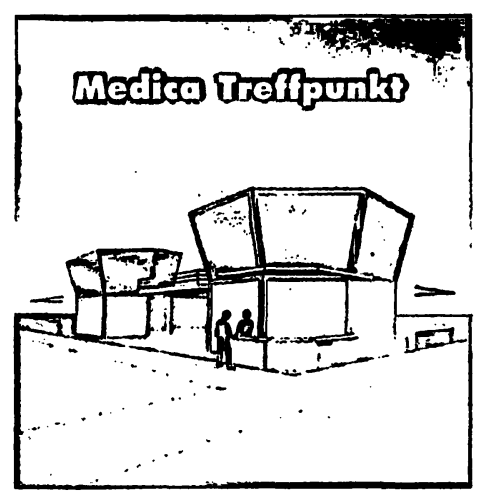

Die Themen des diesjährigen Medica-Treffpunktes Merck sind:

\section{$\square$ Gerätesysteme}

EASY ST, der kleine Analyzer mit den Methoden des großen Labors und das maßgeschneiderte Packungskonzept für den AU 5000 von Olympus.

\section{$\square$ Klinische Chemie}

IMAC, Immunoassays so einfach wie die klassische klinische Chemie, als erster Parameter dieser neuen Technologie die PMN-Elastase. Kontrollseren Qualitrol $^{\otimes}$ und Creatinin als enzymatischer Test.

\section{口 Mikrobiologie}

Anaerocult ${ }^{\circ}$, das Paket für die Anaerobiose, Bactident ${ }^{\circledR}$ Teststäbchen, unser Programm für die Candida-Diagnostik und Fertignährböden.

\section{$\square$ Zelldiagnostik}

Kryofix ${ }^{\otimes}$, Fixiermittel für Gefrierschnitte mit und ohne Mikrowellenstimulation. TissuGnost ${ }^{\circledR}$, immunhistochemische Färbereagenzien und LeucoGnost ${ }^{\oplus}$ zur Leukämiedifferenzierung.

Außerdem präsentieren wir an unserem Stand die Diagnostica Merck PC-Liste und den MerckKatalog auf Diskette sowie Compas, das PC-gestützte Informationssystem für das Labor.

Besuchen Sie uns in Düsseldorf, dort liegt auch wieder unser Diagnostica-Spectrum für Sie bereit.

\section{DIAGNOSTICA MERCK}

E. Merck

Frankfurter Straße 250

D-6100 Darmstadt 1

\section{Biomertra}

HPLC-electrochemical detection with and without BIOSENSORS

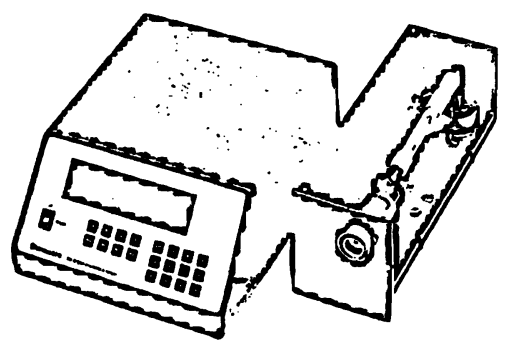

Electrochemical Detector EP 30

highly sensitive determination of clinical relevant compounds

\section{Without BOS ENSORS
O catecholamines}

in blood plasma and

urine by using the new

Biometra glassy carbon

detector cell and the

Biometra-catecholamineskits

with BIOSENSORS
acetylcholine
$O$ choline
O glucose
O galactose
O ethanol
O methanol

in the pmole range

by combination of the Biometra-BIOSENSORS (with immobilized enzymes) and electrochemical detection using the Biometra platinum detector cell

\section{Analyse these substances with the same system simply by chan- ging the BIOSENSOR cartridge}

\section{the company which introduced BIOSENSORS into HPLC}

\section{Biometra}

biomedizinische Analytik $\mathrm{GmbH}$ Wagenstieg 5 - D-3400 Göttingen Tel. (05 51) 3710 32-34 • Fax (05 51) 47655 Telex 965213
Emotzündlumgsdiangmostilk in der Loborrrowinine

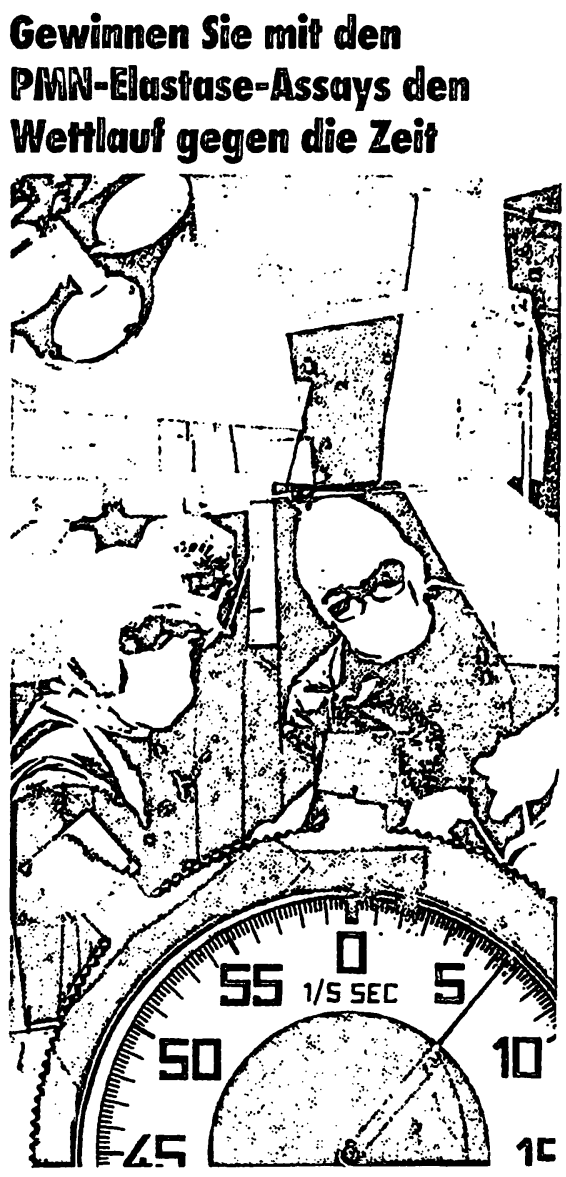

Die PMN-Elastase ist einer der sensitivsten Parameter zur Diagnose einer Entzündung. Die bekannte $2 \mathrm{~h}$-Version ermöglicht die Bestimmung aus Plasma, Stenalmark- un. Synovialflüssigkeit und weiterem Untersuchungsmaterial. Ab Oktobe 1988 steht der homogene Enzymimmunoassay PMN-Elastase IMAC zur Verfügung, er liefert aus dem Plasma innerhalb von 10 Minuten, bei manueller Methode innerhalb von 20 Minuten, die Entscheidungs hilfe für den Kliniker.
DIAGNOSTICA

E. Merck

Frankfurter Straße 250

D-6100 Darmstadt 1 


\section{Bereits 150 Laboratorien in Deutschland arbeitem mit BM/Hitachi 717 Systemen. Dieser Erfolg ist unsere beste Empfehlung.}

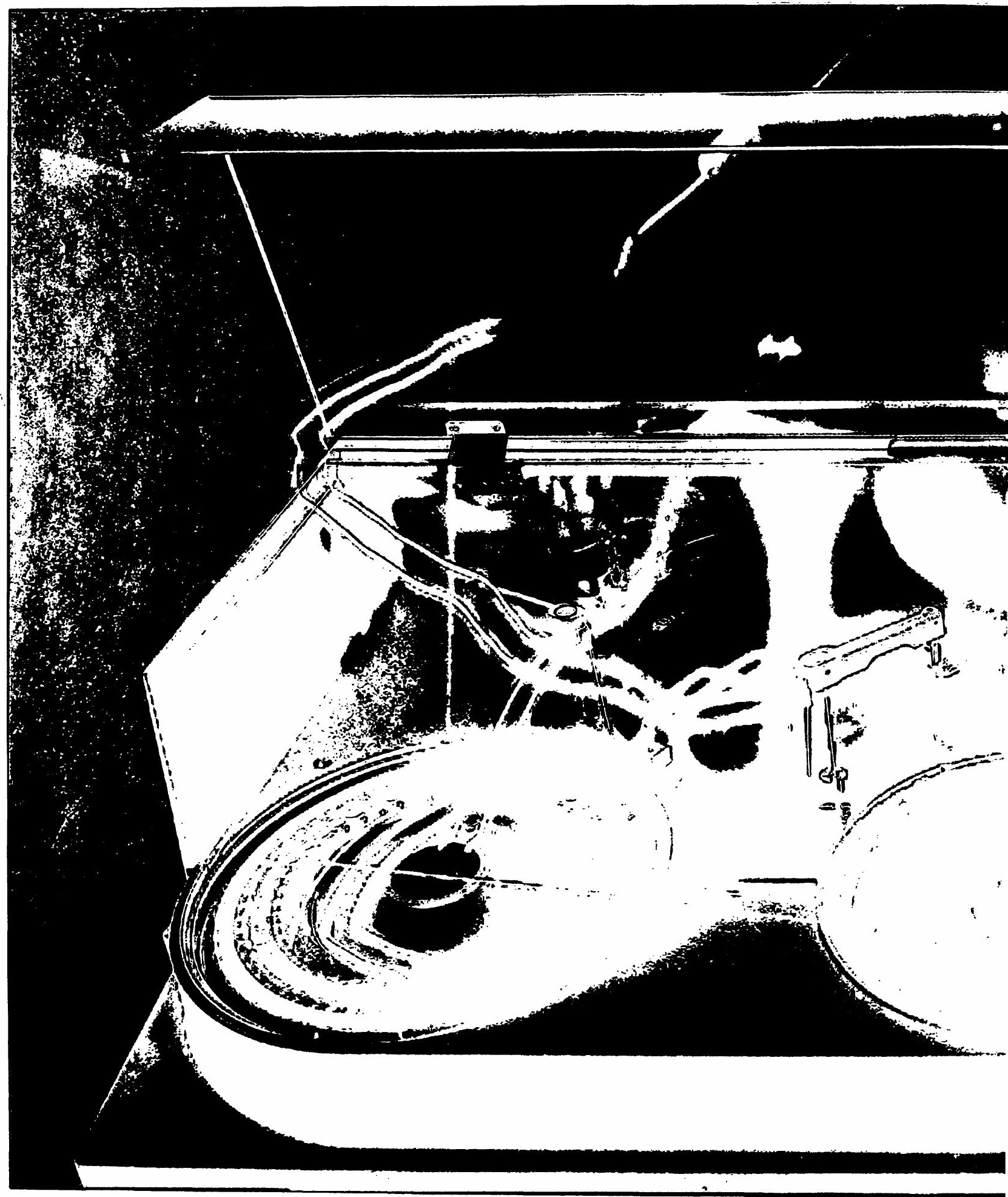




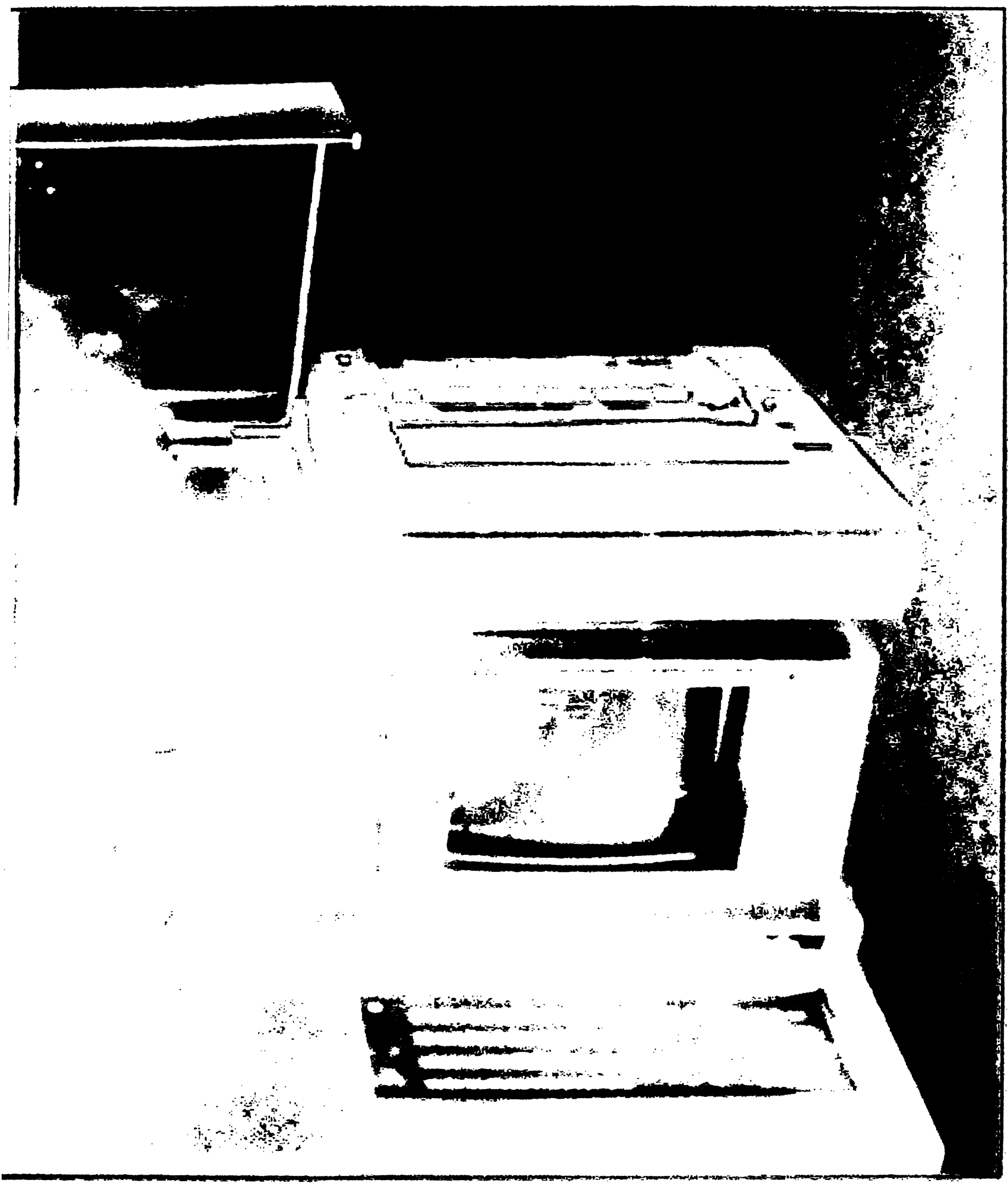

BM/Hifachi 717 .

Domn Sio hobon Answrurth auf 9 lhath

1. 


\section{Vitaminim $\mathbb{D}$}

\section{Molecular, Cellular and Clinical Endocrinology}

Proceedings of the Seventh Workshop on Vitamin D

Rancho Mirage, Califormia, U.S.A. April 1988

Editors A.W. Norman $\cdot$ K. Schaefer $\cdot$ H.-G. Grigoleit $\cdot$ D. v. Herrath

$1988.17 \mathrm{~cm} \times 24 \mathrm{~cm}$. XL, 1072 pages. Numerous illustrations

Hardcover. DM 390,- ISBN 3110114771

The quality of the science presented at the Seventh Workshop on Vitamin D was outstanding. Major developments were made in understanding of Vitamin D on many research frontiers, including those of the chemists, biochemists, physiologists as well as clinicians who attended the meeting and who are actively conducting research in various aspects of the Vitamin $\mathrm{D}$ endocrine system.

\section{From the Contents}

Chemistry of Vitamin D Seco-Steroids - Vitamin D Metabolism and Catabolism Biochemistry and Regulation of Hydroxylases - Receptors for $1,25(\mathrm{OH})_{2} \mathrm{D}_{3}$ (Biochemistry and Molecular Biology) - Cell Differentiation/Hematopoiesis/Immunology $\cdot$ Gene Regulation by $1,25(\mathrm{OH})_{2} \mathrm{D}_{3} \cdot$ Biological Actions of Vitamin D Metabolites Calbindins (Biochemistry, Molecular Biology, Biological Actions) - Author Index $\cdot$ Key Word Index $\cdot$ Cell Line Index

Also available:

\section{Vitamin D}

Uremic Bone Disease: 1974. XXIV, 779 pages. DM 205,-

Basic Research: 1979. XXVIII, 1318 pages. DM 220,-

Calcium Metabolism: 1982. XXVIII, 1286 pages. DM 285,-

Chemical, Biochemical and Clinical Update: 1985. XXXXIII, 1249 pages. DM 340,-

Prices are subject to change without notice

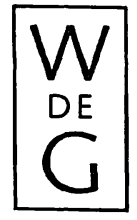
de Gruyter • Berlin • New York

Verlag Walter de Gruyter \& Co., Genthiner Str. 13, D-1000 Berlin 30, Tel.: (0 30) 260 05-0, Telex 184027

Walter de Gruyter, Inc., 200 Saw Mill River Road, Hawthorne, N.Y. 10532, Tel. (914) 747-0110, Telex 646677 


\section{Reference method}

A manual reference method with the chromogen bathophenanthroline sulphonate with deproteinisation (kit from Boehringer Mannheim, FRG No. 124214), which is comparable with the recommended method of The International Committee for Standardization in Hematology (12) was used.

\section{Methods for urine examination}

Standards of $17.9,90.0,179.1$, and $358.2 \mu \mathrm{mol} / 1$ and the same reagents and programming as for serum and plasma determinations (s. above) were used.

\section{Pretreatment of urine samples}

The urine samples were diluted $1: 3.5$ with a solution containing citric acid $(0.57 \mathrm{~mol} / \mathrm{l})$ and ascorbic acid $(0.48 \mathrm{~mol} / \mathrm{l}) ; 0.5 \mathrm{ml}$ of this diluted solution was placed in a capped micro reaction vessel and kept in a heat block (Eppendorf 3401, Eppendorf Gerätebau, Hamburg, FRG) at $56^{\circ} \mathrm{C}$ for $15 \mathrm{~min}$. After this pretreatment, the urine sample was assayed automatically as described above. If the total amount of ferrioxamine iron and transferrin iron in serum is to be determined, serum can be pretreated in the same manner.

\section{Results}

\section{Investigation of different chromogens}

The reaction time for total colour development was found to be $30 \mathrm{~s}$ for tripyridyl-s-triazine, $2 \mathrm{~min}$ for bathophenanthroline sulphonate and ferrozine and $1 \mathrm{~h}$ for ferene-S, examined at $25^{\circ} \mathrm{C}$ and at a $\mathrm{pH}$ of 1.85 (see tab. 2). The four different chromogens were tested under the same standard conditions, using 0.24 $\mathrm{mol} / \mathrm{l}$ citric acid/-HCl-NaOH buffer. Figure 1 indicates that tripyridyl-s-triazine has a constant colour intensity in the $\mathrm{pH}$ range between 1.6 and 4.0 and bathophenanthroline sulphonate in the $\mathrm{pH}$ range 1.3 to at least 6.0. The chromogens ferrozine and ferene$\mathrm{S}$ were found to have a somewhat less constant colour intensity between $\mathrm{pH} 1.6$ and 4.6 and between $\mathrm{pH} 1.7$ and 4.6 , respectively. All reagents were found to be

Tab. 2. Some features of the four different chromogens under the same standard conditions (citrate buffer, $\mathrm{pH}$ 2.0).

\begin{tabular}{llll}
\hline $\begin{array}{l}\text { Colour } \\
\text { reagent }\end{array}$ & $\begin{array}{l}\text { Reaction } \\
\text { time } \\
\text { (min) }\end{array}$ & $\begin{array}{l}\text { Solu- } \\
\text { bility }\end{array}$ & $\begin{array}{l}\text { Molar } \\
\text { absorptivity } \\
\text { under test } \\
\text { conditions } \\
\left(\mathrm{m}^{2} / \mathrm{mol}\right)\end{array}$ \\
\hline $\begin{array}{l}\text { Tripyridyl- } \\
\text { s-triazine }\end{array}$ & 0.5 & + & 220660 \\
$\begin{array}{l}\text { Bathophen- } \\
\text { anthroline } \\
\text { sulphonate }\end{array}$ & 2.0 & + & 219210 \\
$\begin{array}{l}\text { Ferrozine } \\
\text { Ferene-S }\end{array}$ & 2.0 & + & 282360 \\
\hline
\end{tabular}

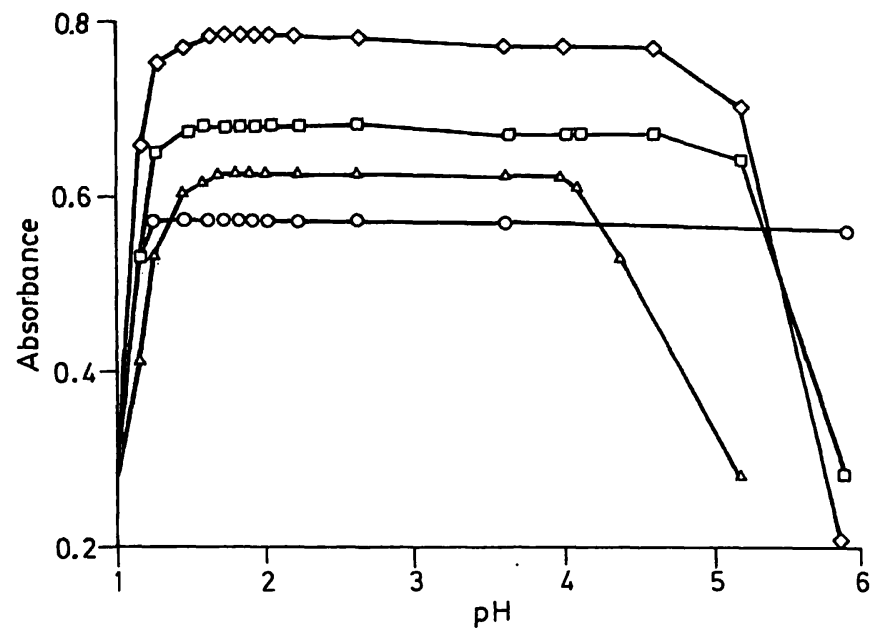

Fig. 1. Colour development and intensity of the four tested chromogens at different $\mathrm{pHs}$ by the use of citrate $/ \mathrm{HCl} /$ $\mathrm{NaOH}$ buffer.

$\diamond=$ Ferene-S

$\square=$ Ferrozine

$\Delta=2,4,6$-Tripyridyl-s-triazine

$\mathrm{O}=$ Bathophenanthroline sulphonate

stable for at least 2 months at $4-8{ }^{\circ} \mathrm{C}$ and 1 week at room temperature. The colour complexes of tripyridyl-s-triazine and ference-S were found to be stable for at least $72 \mathrm{~h}$, and for bathophenanthroline sulphonate and ferrozine for at least 36 and $24 \mathrm{~h}$, respectively. The interference of copper in the tripyridyls-triazine/citrate method was found to be less than $2.0 \%$ in a plasma with various concentrations of added copper chloride, as described in detail elsewhere (13).

\section{Correlations with the reference method}

Sixty different plasma samples from patients were tested with tripyridyl-s-triazine, bathophenanthroline sulphonate, ferrozine and ferene-S and the results compared with those from the reference method. In figure $2 \mathrm{a}$, it is shown that a good correlation was obtained with the tripyridyl-s-triazine method. No interference was observed in this method in icteric, lipaemic or haemolytic plasmas. These findings show clearly that the tripyridyl-s-triazine/citrate method is specific and sensitive for iron determination in human blood. This method detects iron concentrations of less than $0.2 \mu \mathrm{mol} / 1$. Distinctly turbid, lipaemic sera may impair precision and should be pretreated with a commonly available cleaning agent. Interference with the determination of haemoglobin iron arise at $37^{\circ} \mathrm{C}$ on the Greiner system in plasmas with a haemoglobin content of $0.8 \mathrm{~g} / 1$ or more. In the other systems, haemoglobin contents up to $5.0 \mathrm{~g} / 1$ did not interfere, as demonstrated in table 3 . In figure 2 it is shown 

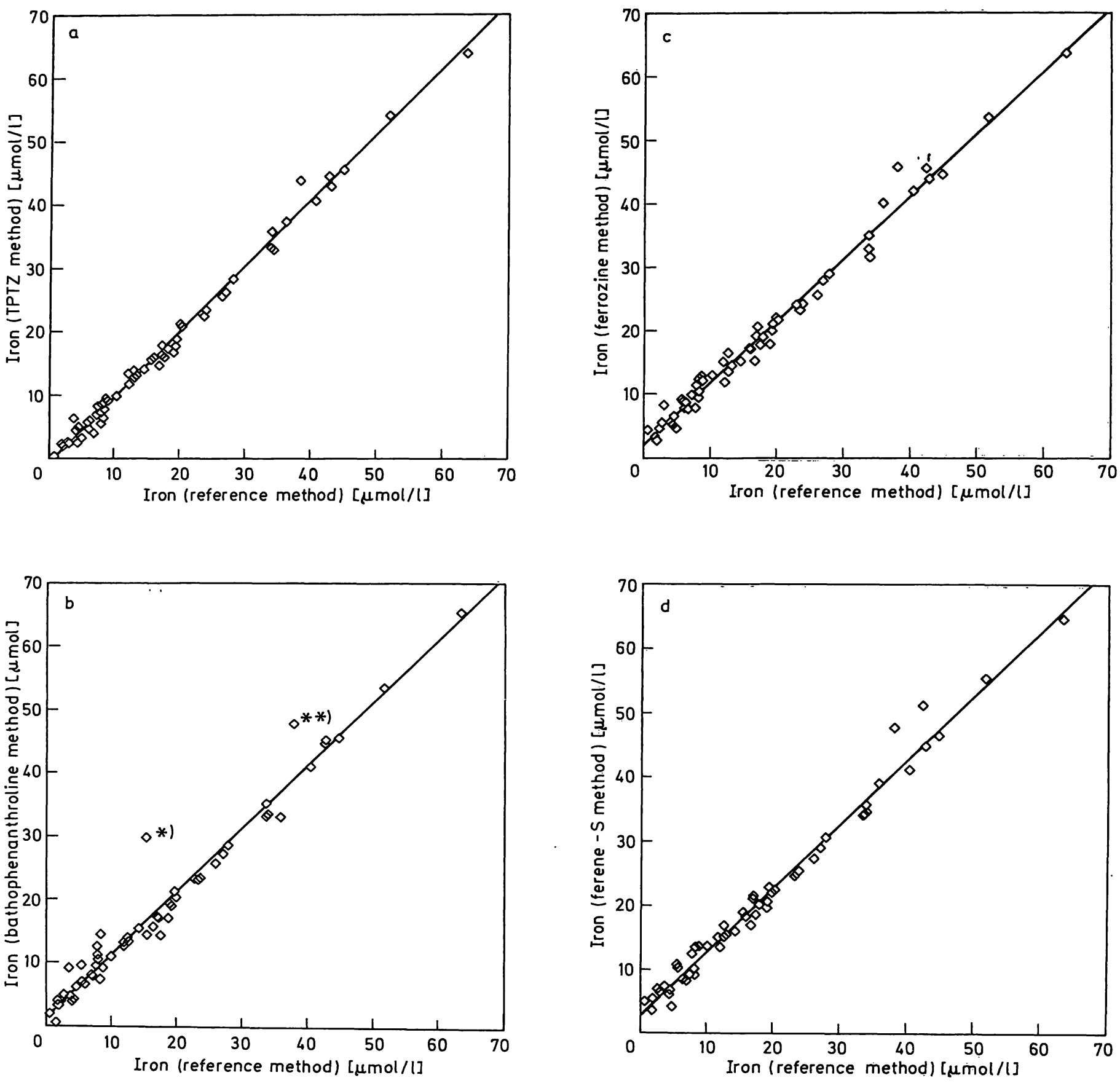

Fig. 2. Correlation data of the four different chromogens with the manual reference method in plasma samples from patients. The chromogens were tested under the same standard conditions (citrate buffer pH 2.0).

a) 2,4,6-Tripyridyl-s-triazine (TPTZ)

Total range: $\quad \mathrm{n}=60 ; \mathrm{r}=0.996 ; \mathrm{y}=0.1035 \mathrm{x}-0.508$

Range $0.7-10.2 \mu \mathrm{mol} / \mathrm{l}: \mathrm{n}=25 ; \mathrm{r}=0.916 ; \mathrm{y}=0.948 \mathrm{x}+0.068$

Range 10.3-63.4 $\mu \mathrm{mol} / \mathrm{l}: \mathrm{n}=35 ; \mathrm{r}=0.995 ; \mathrm{y}=1.045 \mathrm{x}-0.854$

b) Bathophenanthroline

Total range:

$\mathrm{n}=60 ; \mathrm{r}=0.983 ; \mathrm{y}=1.002 \mathrm{x}+1.187$

Range $0.7-10.2 \mu \mathrm{mol} / \mathrm{l}: \mathrm{n}=25 ; \mathrm{r}=0.874 ; \mathrm{y}=1.154 \mathrm{x}+0.776$

Range $10.3-13.4 \mu \mathrm{mol} / \mathrm{l}: \mathrm{n}=35 ; \mathrm{r}=0.974 ; \mathrm{y}=1.03 \mathrm{x}+0.093$

$\left.{ }^{*}\right)$ plasma sample with a bilirubin content of $73.5 \mu \mathrm{mol} / \mathrm{l}$.

**) plasma sample with a bilirubin content of $287.3 \mu \mathrm{mol} / \mathrm{l}$.

c) Ferrocine

Total range: $\quad n=60 ; r=0.992 ; y=0.977 x+2.247$

Range $0.7-10.2 \mu \mathrm{mol} / \mathrm{l}: \mathrm{n}=25 ; \mathrm{r}=0.898 ; \mathrm{y}=1.066 \mathrm{x}+2.078$

Range 10.3-63.4 $\mu \mathrm{mol} / \mathrm{l}: \mathrm{n}=35 ; \mathrm{r}=0.990 ; \mathrm{y}=1.005 \mathrm{x}+1.285$

d) Ferene-S

Total range: $\quad \mathrm{n}=59 ; \mathrm{r}=0.992 ; \mathrm{y}=0.997 \mathrm{x}+2.835$

Range $0.7-10.2 \mu \mathrm{mol} / \mathrm{l}: \mathrm{n}=24 ; \mathrm{r}=0.879 ; \mathrm{y}=1.016 \mathrm{x}+3.030$

Range $10.3-63.4 \mu \mathrm{mol} / \mathrm{l}: \mathrm{n}=35 ; \mathrm{r}=0.989 ; \mathrm{y}=1.023 \mathrm{x}+1.933$ 
Tab. 3. Determination of iron in haemolytic plasma samples. From a blood sample, erythrocytes were haemolysed in distilled water and diluted to different concentrations. Separate fractions of the plasma sample were mixed with the same volume of one of the haemolysate dilutions. The expected value was determined after addition of the same volume of distilled water to a plasma fraction. Haemoglobin was determined with the cyanmethaemoglobin method on a Gilford Stasar III spectral photometer (Gilford Instruments, Oberlin, $\mathrm{OH}$, USA).

\begin{tabular}{lll}
\hline $\begin{array}{l}\text { Hb concentration } \\
(\mathrm{g} / \mathrm{l})\end{array}$ & $\begin{array}{l}\text { Expected value } \\
(\mu \mathrm{mol} / \mathrm{l})\end{array}$ & $\begin{array}{l}\text { Found value } \\
(\mu \mathrm{mol} / \mathrm{l})\end{array}$ \\
\hline 0.62 & 12.2 & 12.5 \\
1.25 & 12.2 & 12.2 \\
2.50 & 12.2 & 12.0 \\
5.05 & 12.2 & 12.3 \\
\hline
\end{tabular}

that the other chromogens have a considerably positive error, particularly in the pathologically decreased range, as also demonstrated in table 4 . In plasmas with iron concentrations above $10.2 \mu \mathrm{mol} / 1$ the correlation with the reference method was found to be improved, and the difference between the 4 different chromogens was found to be almost balanced. Two plasma samples with elevated total bilirubin concentration were found to have a falsely positive error in the bathophenanthroline sulphonate/citrate method at $\mathrm{pH}$ 2.0. These plasma samples (fig. $2 \mathrm{~b}^{*}$ and ${ }^{* *}$ ) had bilirubin concentrations of 73.5 and $278.3 \mu \mathrm{mol} / 1$, respectively, indicating that bilirubin interferes with this method. The latter finding was confirmed in a pooled plasma from 12 different icteric patients. In this pooled plasma, the following data were obtained: total bilirubin $=155.6 \mu \mathrm{mol} / 1$, iron concentration in the tripyridyl-s-triazine method $=17.6 \mu \mathrm{mol} / \mathrm{l}$, iron concentration in the bathophenanthroline sulphonate method $=24.7 \mu \mathrm{mol} / 1$, positive error in the batho-
Tab. 4. List of results $(\mu \mathrm{mol} / \mathrm{l})$ of the four tested methods under the same standard conditions in plasma samples in the pathologically decreased range.

\begin{tabular}{|c|c|c|c|c|c|}
\hline & 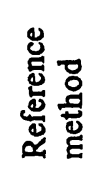 & 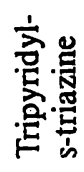 & 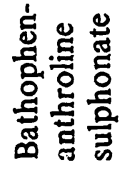 & 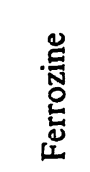 & 品 \\
\hline 1 & 0.70 & 0.40 & 2.00 & 4.50 & 5.00 \\
\hline 2 & 1.80 & 2.30 & 0.50 & 3.40 & 3.90 \\
\hline 3 & 2.00 & 2.00 & 3.90 & 2.70 & 5.60 \\
\hline 4 & 2.30 & 2.00 & 3.20 & 4.70 & - \\
\hline 5 & 2.70 & 2.50 & 4.10 & 5.70 & 7.00 \\
\hline 6 & 3.00 & 2.50 & 5.00 & 8.40 & 6.40 \\
\hline 7 & 3.80 & 6.40 & 9.10 & 5.60 & 7.50 \\
\hline 8 & 3.90 & 4.50 & 4.80 & 5.70 & 6.80 \\
\hline 9 & 4.30 & 2.50 & 3.90 & 5.00 & 6.40 \\
\hline 10 & 4.50 & 5.20 & 4.50 & 6.60 & 7.20 \\
\hline 11 & 4.80 & 3.40 & 6.10 & 5.00 & 4.30 \\
\hline 12 & 5.70 & 5.70 & 9.70 & 9.50 & 10.90 \\
\hline 13 & 5.90 & 5.00 & 7.20 & 9.10 & 10.60 \\
\hline 14 & 6.10 & 6.10 & 6.80 & 8.10 & 8.60 \\
\hline 15 & 6.60 & 3.90 & 7.50 & 7.70 & 8.60 \\
\hline 16 & 7.20 & 7.00 & 7.90 & 9.90 & 9.30 \\
\hline 17 & 7.20 & 8.10 & 7.90 & 9.00 & 9.30 \\
\hline 18 & 7.70 & 5.70 & 8.20 & 7.90 & 9.30 \\
\hline 19 & 7.90 & 8.40 & 9.70 & 11.50 & 12.50 \\
\hline 20 & 8.20 & 6.60 & 12.70 & 12.90 & 13.30 \\
\hline 21 & 8.20 & 7.90 & 11.30 & 9.70 & 9.50 \\
\hline 22 & 8.20 & 9.00 & 10.60 & 10.70 & 10.40 \\
\hline 23 & 8.60 & 8.60 & 14.50 & 13.10 & 13.30 \\
\hline 24 & 9.00 & 9.30 & 9.30 & 12.20 & 13.60 \\
\hline 25 & 10.20 & 9.90 & 11.10 & 13.10 & 13.80 \\
\hline
\end{tabular}

phenanthroline sulphonate method $=40.3 \%$. By increasing (decreased plasma/reagent ratio) the $\mathrm{pH}$ in the direct bathophenanthroline sulphonate method from $\mathrm{pH} 2.0$ to $\mathrm{pH} 4.0$, the interference by bilirubin was abolished. Thus, the bathophenanthroline sulphonate/citrate method seems to be specific for iron measurement at the latter $\mathrm{pH}$. No significant difference in the iron concentration could be detected between human serum and plasma.

Tab. 5. Data on the intra-assay precision of the tripyridyl-s-triazine method in different control sera.

\begin{tabular}{|c|c|c|c|c|c|c|}
\hline $\begin{array}{l}\text { Control } \\
\text { serum }\end{array}$ & $\begin{array}{l}\text { Charge } \\
\text { No. }\end{array}$ & $\begin{array}{l}\text { Assigned } \\
\text { value }^{1} \\
(\mu \mathrm{mol} / \mathrm{l})\end{array}$ & $\mathbf{n}$ & $\begin{array}{l}\text { Found } \\
\text { mean value } \\
(\mu \mathrm{mol} / \mathrm{l})\end{array}$ & $\mathrm{SD}$ & $\begin{array}{l}\text { CV } \\
(\%)\end{array}$ \\
\hline $\begin{array}{l}\text { Decision L } 1 \\
\text { (Beckman) }\end{array}$ & C 401202 & 21.1 & 30 & 22.5 & 0.25 & 1.11 \\
\hline $\begin{array}{l}\text { Decision L } 2 \\
\text { (Beckman) }\end{array}$ & C 401203 & 28.8 & 30 & 32.2 & 0.30 & 0.93 \\
\hline $\begin{array}{l}\text { Decision L } 3 \\
\text { (Beckman) }\end{array}$ & C 401204 & 41.5 & 30 & 47.0 & 0.34 & 0.72 \\
\hline $\begin{array}{l}\text { Kontrollogen-LP } \\
\text { (Behringwerke) }\end{array}$ & 623208 & $35.5^{2}$ & 30 & 41.2 & 0.89 & 2.17 \\
\hline $\begin{array}{l}\text { Seronorm } \\
\text { (E. Merck) }\end{array}$ & 162 & 26.3 & 30 & 26.4 & 0.48 & 1.82 \\
\hline
\end{tabular}

\footnotetext{
1 bathophenanthroline sulphonate without deproteinization.

2 ferrozine without deproteinization.
} 
Accuracy and precision in control sera

The best precision in the tripyridyl-s-triazine method was obtained in non-lyophilized sera with a CV ranging from 0.72 to $1.11 \%$ (within one run), as shown in table 5 . The day-to-day variation and mean accuracy for Seronorm were $2.4 \%$ and $+0.5 \%$, respectively.

\section{Adaptation to other automated systems}

The tripyridyl-s-triazine/citrate method was adapted to a Technicon SMAC II and Technicon RA 1000 (13), Eppendorf Epos and Abbot Spectrum automated analysers. The method can be run at any commonly used temperature. In the latter two systems, some modifications are necessary ${ }^{1}$ ).

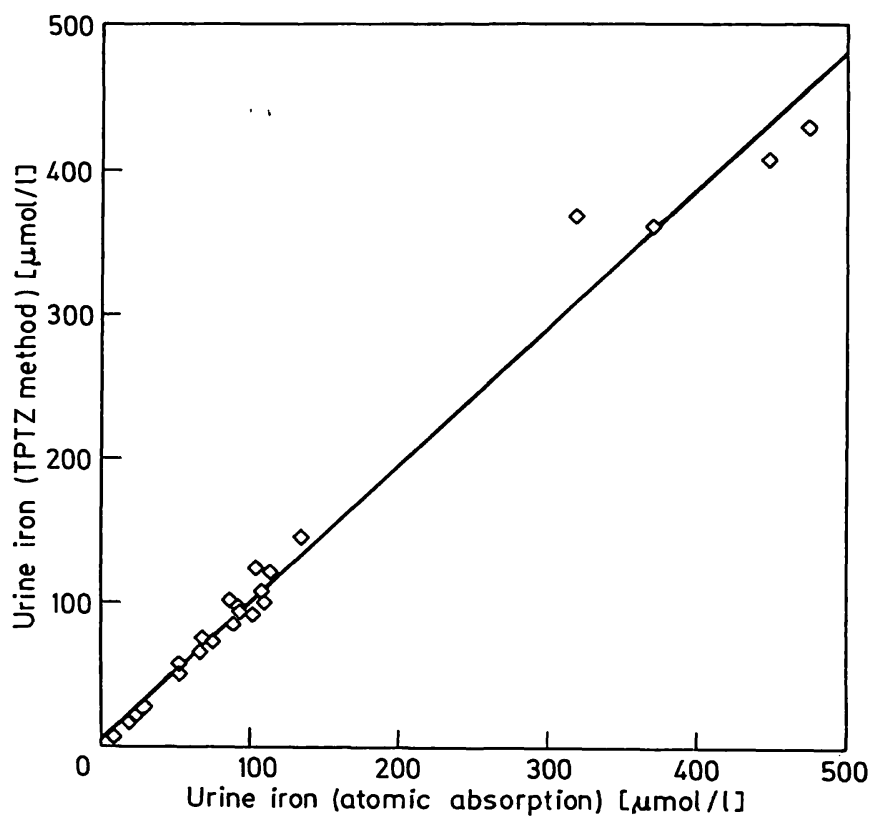

Fig. 3. Correlation data of the 2,4,6-tripyridyl-s-triazine (TPTZ) method with the atomic absorption spectrophotometric method in urine samples.

$\mathrm{n}=26 ; \mathrm{r}=0.992 ; \mathrm{y}=0.950 \mathrm{x}+5.834$

\section{Ferrioxamine iron in urine}

In order to release all desferal-bound iron during sample pretreatment at $56^{\circ} \mathrm{C}$, different molarities of citric acid and ascorbic acid were investigated. At 0.57 $\mathrm{mol} / 1 \mathrm{litric}$ acid and $0.48 \mathrm{~mol} / \mathrm{l}$ ascorbic acid, all ferrioxamine-bound iron was released for the tripyridyl-s-triazine reaction, as determined in urines with known ferrioxamine iron content. This pretreatment can also be used for serum samples, if both ferrioxamine iron and transferrin iron are to be determined.

1) Data on the programming of the Eppendorf Epos and Abbott Spectrum systems are available from the author.
The correlation data between the tripyridyl-s-triazine method and the atomic absorption method in urine samples is demonstrated in figure 3 . These findings are in accordance to the data obtained in iron-free urine samples after addition of desferal and iron (II) chloride at various concentrationsi(not shown).

\section{Discussion}

The present investigation clearly shows that our tripyridyl-s-triazine/citrate method is specific and sensitive for direct iron measurements in human blood, and even in plasmas with iron values of $0.2 \mu \mathrm{mol} / 1$ or less. The high specificity of tripyridyl-s-triazine is consistent with an earlier report (14). Moreover, the simple reagent composition, high reagent stability and the instant colour development in the tripyridyl-striazine method are features of great practical importance, which facilitate an adaptation to other automated systems. It has previously been pointed out that tripyridyl-s-triazine, in contrast to ferrozine, is quite insoluble in water $(14 \div 15)$. This seems to be the main reason why tripyridyl-s-triazine has found only limited use. Under our standard conditions, at an acidic $\mathrm{pH}$, tripyridyl-s-triazine was totally soluble within few minutes.

The reaction time of $1 \mathrm{~h}$ found with ferene-S is somewhat longer than reported by Eskelinen (11). Colour development within approx. $2 \mathrm{~min}$ in the bathophenanthroline sulphonate- and ferrozine methods and within approx. $30 \mathrm{~s}$ for tripyridyl-s-triazine is therefore an obvious advantage. In our automated systems, a relatively good precision was obtained with ferene$\mathrm{S}$, even after an incubation time of only $5 \mathrm{~min}$. The high sensitivity of ferene-S is only of limited value under these conditions. On the other hand, a reaction time of more than 5 to $10 \mathrm{~min}$ limits the usefullness of a method in an automated system. The positive error in the ferrozine and ferene-S method indicates interference by copper, in accordance with an earlier report (11). We have no explanation at present for the interference of bilirubin at $\mathrm{pH} 2.0$ in the direct bathophenanthroline sulphonate/citrate method. In view of this interference, the bathophenanthroline sulphonate method is not suitable as a micromethod under our standard conditions. In contrast to bathophenanthroline sulphonate, tripyridyl-s-triazine is available at low cost.

Both the reducing and chelating effect of citric acid and the rapid release of iron from transferrin at the low $\mathrm{pH}$ are advantageous. The coloured ferroin complexes also seem to be stabilized in our method, giving a constant colour development in ${ }^{\circ}$ a relatively wide 
$\mathrm{pH}$-range, in contrast to $\mathrm{HCl}$-glycine-Tween buffer at the same $\mathrm{pH}$ (16). By the use of less sensitive photometric equipment, the latter finding enables a decrease in the ratio, sample/reagent volume, and hence an increase in $\mathrm{pH}$.

The wide linear range of the ferrioxamine iron determination in urine samples with a high iron content is advantageous. During desferal treatment, an increase in the serum iron concentration occurs (17). Without pretreatment of the serum samples, our method will release some ferrioxamine iron. Since desferal partly binds transferrin iron (18), a decrease in the serum transferrin iron during desferal treatment can be ex- pected. The quantity of released ferrioxamine iron may vary widely under different standard conditions. Direct serum iron determinations during desferal therapy might thus be rather uncertain. In contrast to an earlier report (19), we found no evidence for the sensitivity of tripyridyl-s-triazine to desferal under our standard conditions. Pretreatment of samples permits the determination of the total ferrioxamine iron and transferrin iron in serum.

\section{Acknowledgement}

We wish to thank Mrs. Helma Maigatter and Mrs. Christine Meyer for their skilful technical assistance.

\section{References}

1. Young, D. S. \& Hicks, J. M. (1965) J. Clin. Pathol. 18, 98-102.

2. Kauppinen, V. \& Gref, G.-C. (1967) Scand. J. Clin. Lab. Invest. $20,24-28$.

3. Giovanniello, T. J., DiBenedetto, G., Palmer, D. W. \& Peters, T. Jr. (1968) J. Lab. Clin. Med. 71, 874-883.

4. Werkman, H. P. T., Trijbels, J. M. F., van Munster, P. J. J., Schretlen, E. D. A. M. \& Moerkerk, C. (1971) Clin. Chim. Acta 31, 395-401.

5. Yee, H. Y. \& Zin, A. (1971) Clin. Chem. 17, 950-953.

6. Bjerve, K. S. (1976) Scand. J. Clin. Lab. Invest. 36, $673-677$.

7. Levinson, S. S. (1980) Clin. Chem. 26, 671-672.

8. Viollier, M. A., Gschwind, H. \& Schläpfer, P. (1980) Lab. Med. 4, 240-244.

9. Mori, L., Bekkering, A., Traini, J. \& Vanderlinden, L. (1981) Clin. Chem. 27, 1441-1444.

10. Ceriotti, F. \& Ceriotti, G. (1980) Clin. Chem. 26, $327-$ 331.

11. Eskelinen, S., Haikonen, M. \& Räisänen, S. (1983) Scand. J. Clin. Lab. Invest. 43, 453-455.

12. International Committee for Standardization in Hematology (1971) Blood 37, 598-600.

13. Seiffert, U. B., Solem, E. \& Zirker, M. (1988) Lab. Med. $12,174-178$.

14. Collins, P. F. \& Diehl, H. (1959) Anal. Chem. 31, 18621867.

15. Stookey, L. L. (1970) Anal. Chem. 42, 779-781.

16. Ichida, T., Osaka, T. \& Kojima, K. (1968) Clin. Chim. Acta $22,271-275$.

17. Wöhler, F. (1964) Acta Haematol. 32, 321-337.

18. Keberle, H. (1964) Ann. N. Y. Acad. Sci. 119, 758- 768.

19. van Stekelenburg, G. J., Valk, C. \& de Boer, G. J. (1982) Clin. Chem. 28, 2328-2329.

PD Dr. E. Solem

Laboratorien

Zentrum der Kinderheilkunde

der Universitätskliniken

Theodor-Stern-Kai 7

D-6000 Frankfurt am Main 70 
